\title{
ПРОДУКТИВНІСТЬ АУТБРЕДНОЇ ТА ІНБРЕДНОЇ ХУДОБИ БІЛОГОЛОВОЇ УКРАЇНСЬКОЇ ПОРОДИ
}

\author{
Войтенко Світлана Леонідівна \\ доктор сільськогосподарських наук, профресор \\ Інститут розведення і генетики тварин імені М.В.Зубця НААН \\ ORCID: 0000-0002-7196-8700 \\ E-mail: slvoitenko@ukr.net
}

Сидоренко Олена Василівна кандидат сільськогосподарських наук, старший науковий співробітник Інститут розведення і генетики тварин імені М.В.Зубця НАAН ORCID: 0000-0003-2429-9361 E-mail: sydorenkoolena@ukr.net

Серед методів чистопородного розведення сільськогосподарських тварин особливу зацікавленість у дослідників викликає інбридинг, без якого не можливо обійтися не лише при виведенні порід сільськогосподарських тварин, але й при збереженні біологічного різноманіття та унікальних якостей місцевих порід. I хоча проблема інбридингу має давню історію вивчення, вона достатньо складна й багатогранна навіть зараз, за сучасного розвитку генетики та селекції з урахуванням чого потребує подальщих напрацювань, пошуку способів управляння стадом та породою, особливо за умови, коли порода нечисельна й розводять закритою популяцією. Дослідження проводили на аутбредних та інбредних телицях і коровах білоголової української породи в ТОВ «Подільський господар» Хмельницької області, які були розподілені на 5 піддослідних груп залежно від ступеня спорідненості та коефіцієнту інбридингу. Вивчали живу масу телиць в процесі вирощування, відтворну здатність та надій корів-первісток за матеріалами бази даних системи управління молочним скотарством СУМС «Інтесел-Орсек». Встановлено, що аутбредні та інбредні телиці білоголової української породи в процесі вирощування від народження до 18-місячного віку різнилися між собою за живою масою, але різниця між групами була статистично недостовірною. В різні періоди росту перевагу мали як аутбредні, так і інбредні тварини, засвідчуючи можливість використання в стаді нарівні з неспорідненим розведенням спорідненого. Загалом за період росту від народження до 18-місячного віку аутбредні телиці за живою масою переважали тварин групи віддаленого і тісного інбридингу на 6,0 ке і 2,0 ке, але поступалися представницям помірного та близького ступенів інбридингу на 3,0 і 13,0 ке, відповідно. Доцільність отримання та використання інбредних тварин білоголової української породи підтверджують $i$ результати вивчення відтворної здатності корів, згідно яких інбредних корів осіменяли раніше за аутбредних на 0,5-0,9 місяців. Водночас аутбредні крови за першу лактацію продукували на 41-292 кг молока більше, ніж інбредні віддаленого, помірного та близького ступенів інбридингу, але на 150 кг менше за групу корів тісного ступеня інбридингу без статистично достовірної різниці між групами. 3 урахуванням чого зроблений узагальнюючий висновок про можливість спорідненого розведення худоби білоголової української породи.

Ключові слова: мюетоди розведення, локальна порода, худоба, picm, продуктивність.

DOI: https://doi.org/10.32845/bsnau.Ivst.2020.2.6.

Вступ. Загальновідомо, що до методів чистопородного розведення відносять аутбридинг та інбридинг, біологічна сутність яких полягає у збереженні і підсиленні цінних властивостей родоначальника в поколіннях, але в першому випадку спаровують тварини неспоріднених між собою, а в другому - споріднених [19]. 3-поміж цих двох методів найбільшу зацікавленість у дослідників викликає саме інбридинг, без якого неможливо обійтися при виведенні порід сільськогосподарських тварин, оскільки він консолідує популяцію за певними ознаками та тиражує цінні якості видатних предків $[9,14,24]$.

У розробленні теорії інбридингу у тваринництві особливе місце належить селекціонерам, генетикам і біологам, які починаючи з XVIII століття й до цього часу намагаються знайти методологічні підходи до визначення рівня гомозиготності тварин та послаблення негативної дії спорідненого підбору, тим більше, що ступінь реакції на даний метод розведення у різних видів тварин неоднаковий $[12,15,16$, 27]. Зроблене припущення, що негативний вплив спорідненого розведення у вигляді інбредної депресії проявляється за ознаками, які мають полігенний тип успадковування та низьку успадковуваність [7, 8, 20].

Вісник Сумського національного аграрного університету

На думку деяких науковців, небажаний ефект інбридингу може привести до порушення генної рівноваги в популяції, появи летальних рецесивних генів та зниження продуктивності інбредних тварин [32, 37, 39].

Доведений зв'язок патологій у худоби різних порід із збільшенням ступеня інбридингу. Підвищення ступеня гомозиготності на $1 \%$ приводить до зменшення надою корів на 15,9 кг, виходу молочного жиру - на 1,37 кг, білку - 0,6 кг за одночасного збільшення тривалості сервіс-періоду на 1,96 днів, тяжкості отелень на 1,4\% та інших ознак продуктивносTi [35].

Практикою країн з розвиненим скотарством на фоні інтенсифікації галузі відмічене зниження генетичної мінливості основних селекційних ознак у худоби та зростання інбредної депресії, яка супроводжується зниженням молочної продуктивності корів та підвищенням частоти народження телят з генетичними аномаліями [10, 33, 34, 36, 38].

Водночас за переконаннями ряду вчених, споріднене розведення, якщо його застосовувати непостійно і нестихійно, не приводить до негативних наслідків $[4,30]$ і навіть якщо не можна уникнути його систематичного використання, слід не допускати кровозмішування чи тісного інбридингу [1, 
6, 31]. Підтвердженнями чого слугують результати досліджень продуктивності аутбредних та інбредних корів української чорно-рябої молочної породи ступінь інбридингу яких знаходився в межах 2,7-25\%. Вченими не виявлено різниці між молочною продуктивністю, віком першого отелення та продуктивного довголіття у аутбредних та інбредних корів, але визнано, що із збільшенням коефіцієнта інбридингу на $1 \%$ міжотельний період у корів збільшувався на 1,7 днів, а сервіс-період - на 1,3 дні [2].

В практиці тваринництва цілеспрямований інбридинг, особливо комплексний на групу предків, вважається ефективним прийомом селекційно-племінної роботи з породою. Такий метод сприяє витісненню небажаної спадковості та є необхідним елементом створення нових порід чи перебудови існуючих [18].

З'ясовано, що метод спорідненого розведення у комплексі $з$ жорстким добором сприяє виведенню тварин, здатних стійко передавати генетичний потенціал продуктивності своїм потомкам [13, 21, 26]. Споріднене спаровування сприяло одержанню корів-рекордисток в симентальській породі, а поєднання інбредних тварин однієї лінії за внутрішньопородного підбору - забезпечило покращення показників вмісту жиру й білку в молоці [5].

Позитивно оцінюють метод інбридингу при роботі з великою рогатою худобою й інші науковці. Встановлено, що найбільшу кількість молока за першу лактацію одержано від корів чорно-рябої голштинизованої худоби, ступінь інбридингу яких 12,5\%. Вплив інбридингу різних ступенів не приводить до істотної різниці живої маси корів, але інбредні корови, порівняно з аутбредним, народжували більше бугайців, а не теличок [17].

Порівняльний аналіз молочної продуктивності чистопородних та голштинизованих корів ярославської породи за різних варіантів спорідненого і неспорідненого підбору засвідчив одержання найвищого надою, вмісту жиру й білку в молоці за третю та вищу лактацію у групі чистопородних корів віддаленого ступеня інбридингу. Серед голштинизовних корів ярославської породи найвища молочна продуктивність одержана у групі тварин, одержаних за поєднання батьківських пар віддаленого та помірного ступенів інбридингу. Аутбредні корови за першу лактацію достовірно перевищували інбредних лише за жирномолочністю [11]. Тобто, в нечисленних локальних породах споріднене розведення може бути методом удосконалення стада.

3'ясовано, що тривале цілеспрямоване споріднене розведення худоби української червоної молочної породи, крім варіанту тісного інбридингу, не порушує відтворювальних функцій корів, а навпаки, деякою мірою узгоджує розвиток їх продуктивних і репродуктивних ознак. Визнано, що для консолідації селекційних ознак у потомстві варто використовувати помірний інбридинг, а також враховувати розвиток стада та напрям селекції в ньому [25].

На позитивний вплив ступеня інбридингу на молочною продуктивністю корів червоної степової породи вказують і інші дослідники. Доведено, що найнижчий надій за першу і третю лактацію, 3631 і 4032 кг, відповідно, мали інбредні корови типу кровозмішування. Корови груп тісного і помірного інбридингу переважали аутбредних за надоєм першої і третьої лактації, при цьому найвищий надій за першу лактацію мали корови тісного інбридингу - 4640 кг, а за третю лактацію - помірного - 5269 кг, відповідно [23].

На особливу актуальність споріднене розведення заслуговує при збереженні біологічного різноманіття та унікальних якостей місцевих порід сільськогосподарських тварин, а також коли в процесі виробництва молока використовується обмежена кількість бугаїв-плідників, здебільшого голштинської породи [28]. Доведено, що впродовж 15 років генеалогічна однорідність бугаїв різних ліній української чорнорябої молочної, української червоно-рябої молочної та української бурої молочної порід підвищилася на 35-45\%. Вбачається необхідність жорсткого контролювання ступеня інбридингу при підборі батьківських пар для відтворення [28].

Із вищевикладеного видно, що проблема інбридингу, хоча й має давню історію вивчення, складна й багатогранна й не має єдиної точки зору серед біологів, генетиків і селекціонерів, а ставлення до неї практиків і науковців здебільшого протилежне. 3 урахуванням чого, проблема спорідненого розведення була і залишається актуальною з теоретичної і практичної точки зору, потребує подальших напрацювань, пошуку способів управляння стадом та породою, особливо за умови, коли порода нечисельна й розводять закритою популяцією.

Матеріали та методи досліджень. Дослідження проведені на телицях та коровах білоголової української породи в ТОВ «Подільський господар» Хмельницької області в рамках виконання НТП «Збереження генофонду сільськогосподарських тварин». Худобу білоголової української породи відносять до локальної нечисленної популяції, яку впродовж багатьох років утримують лише в племінному стаді даного господарства і наразі налічує 300 корів. Розведення худоби здійснюється методами чистопородного розведення, в результаті чого в стаді $€$ інбредні тварини. Для досліджень були відібрані корови 2010-2014 років народження, яких використовували в стаді при виробництві молока у 2017 році.

Для проведення досліджень тварини були розподілені на 5 груп залежно від ступеня спорідненості та коефріцієнту інбридингу: I група - аутбредні; II група - коесріцієнт інбридингу $F_{x}=0,39-0,59 \%$ (віддалений ступінь); III група $F_{x}=0,78-2,93 \%$ (помірний); IV група $-F_{x}=3,13-11,72 \%$ (близький) та $V$ група - $F_{x}=12,5-29,7 \%$ (тісний). Живу масу тварин визначали шляхом зважування в обумовлені вікові періоди. Надій молока корів за 305 днів першої лактації, їх вік першого осіменіння та отелення, а також живу масу в ці періоди визначали за матеріалами бази даних системи управління молочним скотарством (СУМС «Інтесел-Орсек») станом на 1 січня 2018 року. Статистичне опрацювання матеріалів досліджень зроблено за використання програмного пакету «STATISTICA 10.0» на ПК.

Результати досліджень. Встановлено, що аутбредні та інбредні телиці білоголової української породи в процесі вирощування від народження до 18-місячного віку різнилися між собою за живою масою, але ця різниця була статистично недостовірна (табл. 1). За варіювання показнику живої маси народжених телят у межах 29 - 34 кг, найбільш масивними при народженні були тварини тісного ступеня інбридингу (V група), які переважали своїх аутбредних ровесників на 4,0 кг, а з нижчим ступенем інбридингу (II - IV групи) - на 3,0-5,0 кг. 
Таблиця 1

Жива маса аутбредних та інбредних телиць (M $\pm m)$, кг

\begin{tabular}{|c|c|c|c|c|c|}
\hline \multirow[b]{2}{*}{ Вік, міс. } & \multicolumn{5}{|c|}{ Група (ступінь інбридингу) } \\
\hline & $\begin{array}{c}\text { I } \\
\text { (аутбридинг) }\end{array}$ & $\begin{array}{c}\text { II } \\
\text { (віддалений) }\end{array}$ & $\begin{array}{c}\text { III } \\
\text { (помірний) }\end{array}$ & $\begin{array}{c}\mathrm{IV} \\
\text { (близький) }\end{array}$ & $\begin{array}{c}\mathrm{V} \\
\text { (тісний) }\end{array}$ \\
\hline $\mathrm{n}$ & 58 & 18 & 43 & 64 & 20 \\
\hline При народженні & $30 \pm 0,98$ & $31 \pm 1,18$ & $29 \pm 0,91$ & $31 \pm 0,56$ & $34 \pm 1,81$ \\
\hline 3 & $68 \pm 2,58$ & $74 \pm 3,94$ & $72 \pm 2,23$ & $74 \pm 1,91$ & $76 \pm 3,13$ \\
\hline 6 & $129 \pm 3,01$ & $132 \pm 7,18$ & $136 \pm 4,51$ & $134 \pm 3,17$ & $126 \pm 4,09$ \\
\hline 9 & $182 \pm 4,56$ & $182 \pm 10,57$ & $187 \pm 6,65$ & $187 \pm 4,68$ & $179 \pm 6,18$ \\
\hline 12 & $231 \pm 5,87$ & $227 \pm 13,97$ & $233 \pm 7,99$ & $241 \pm 5,99$ & $231 \pm 9,6$ \\
\hline 15 & $282 \pm 7,17$ & $268 \pm 14,56$ & $281 \pm 9,61$ & $291 \pm 7,78$ & $282 \pm 7,10$ \\
\hline 18 & $325 \pm 7,91$ & $320 \pm 14,33$ & $327 \pm 9,97$ & $337 \pm 7,48$ & $327 \pm 6,19$ \\
\hline
\end{tabular}

За живою масою у віці 3-х місяців аутбредні телята поступалися інбредним на 4,0 - 8,0 кг за найвищої живої маси у групі телят тісного ступеня інбридингу. Різниця за живою масою у 6-місячному віці між аутбредними й інбредними телятами, крім групи тісного інбридингу, була теж відчутною й становила 3,0 - 7,0 кг. При цьому найбільшу перевагу над аутбредними телятами мали тварини помірного ступеня інбридингу. У телята тісного ступеня інбридингу (V група) встановили відставання від представників 3 нижчим ступенем інбридингу на 6,0 -10,0 кг та на 3,0 кг - від аутбредних. В наступний віковий період росту тварин - 9 місяців, аутбредні телиці за досліджуваною селекційною ознакою поступалися на 5,0 кг лише особинам помірного і близького ступеня інбридингу, але переважали тварин тісного інбридингу на 3,0 кг. Аналогічна ситуація отримана щодо живої маси піддослідних тварин у 12-місячному віці, коли аутбредні телиці за живою масою на 2,0-10,0 кг поступалися представницям III і IV піддослідних груп, але були масивнішими на 4,0 кг за представниць II групи й знаходилися на рівні тварин $\mathrm{V}$ групи. У наступний період росту - 15 місяців, піддослідні тварини теж були неоднорідними за живою масою, але при цьому аутбредні телиці перевищували інбредних віддаленого і помірного ступеня інбридингу на 1,0-14,0 кг, були однакові з представницями тісного інбридингу, але поступалися групі близького ступеня інбридингу на 9,0 кг. Заключний період вирощування телиць, який закінчується у віці 18 місяців, засвідчив вищу живу масу аутбредних тварин лише порівняно з інбредними віддаленого ступеня інбридингу на 5,0 кг. 3 тваринами помірного, близького та тісного ступеня інбридингу у телиць неспорідненого розведення різниця становила 2,0; 12,0 і 2,0 кг, відповідно.

За результатами вивченої живої маси аутбредних та інбредних телиць білоголової української породи зроблено висновок про відсутність негативного впливу спорідненого розведення на ріст тварин від народження до 18 місяців. В окремі вікові періоди аутбредний молодняк переважав інбредних тварин тієї чи іншої групи, але різниця між ними була статистично недостовірною.

Підтверджує відсутність достовірної різниці між групами тварин і жива маса телиць за увесь період їх вирощування, яка у представниць I групи становила 295 кг, II - 289 кг, III -298 кг, IV - 308 кг і V - 293 кг, відповідно. Тобто, аутбредні телиці білоголової української породи за живою масою під час вирощування були кращими порівняно з тваринами віддаленого інбридингу (II група) на 6,0 кг і тісного (V група) - на 2,0 кг, але поступалися іншим групам на 3,0 -13,0 кг. 3 урахуванням чого можна вважати, що споріднене розведення віддаленого, помірного, близького та тісного ступенів інбридингу не приведе до появи телиць, які в процесі вирощування істотно відставатимуть у рості від своїх аутбредних ровесників.

Використовуючи кореляційний аналіз ми визначили, що жива маса телят при народженні, яку вважають одним 3 критерієм їх відбору, хоча й мала здебільшого прямий зв'язок, але достовірно не узгоджувалася з живою масою у подальші періоди росту. Для аутбредних телиць добір за живою масою при народженні не сприятиме істотному збільшенню показнику в процесі росту з огляду на невисокі коефріцієнти кореляції між ознаками $(r=+0,142 \ldots+0,308)$ (табл. 2). Для телят віддаленого ступеня інбридингу добір за живою масою при народженні супроводжуватиметься деяким підвищенням показнику у подальші періоди їх росту, підтвердженням чого слугують коефіцієнти кореляції між ознаками, які знаходяться в межах $r=+0,457 \ldots+0,601$.

Таблиця 2

Коефіцієнт кореляції між живою масою телят при народженні та в процесі вирощування (r $\left.\pm \mathrm{m}_{\mathrm{r}}\right)$

\begin{tabular}{|c|c|c|c|c|c|}
\hline \multirow[b]{2}{*}{ Корелюючі ознаки } & \multirow[b]{2}{*}{$\begin{array}{c}\text { I } \\
\text { (аутбридинг) }\end{array}$} & \multicolumn{4}{|c|}{ Група (ступінь інбридингу) } \\
\hline & & $\begin{array}{c}\text { II } \\
\text { (віддалений) }\end{array}$ & $\begin{array}{c}\text { III } \\
\text { (помірний) }\end{array}$ & $\begin{array}{c}\mathrm{IV} \\
\text { (близький) }\end{array}$ & $\begin{array}{c}\mathrm{V} \\
\text { (тісний) }\end{array}$ \\
\hline \multicolumn{6}{|c|}{ Жива маса при народженні } \\
\hline 3 мiс. & $0,279 \pm 0,179$ & $0,514 \pm 0,303$ & $0,487 \pm 0,226$ & $0,264 \pm 0,176$ & $-0,739 \pm 0,336$ \\
\hline 6 мiс. & $0,308 \pm 0,134$ & $0,477 \pm 0,311$ & $0,18 \pm 0,154$ & $0,289 \pm 0,175$ & $-0,463 \pm 0,443$ \\
\hline 9 мic. & $0,146 \pm 0,089$ & $0,601 \pm 0,283$ & $-0,122 \pm 0,106$ & $0,344 \pm 0,171$ & $-0,001 \pm 0,00001$ \\
\hline 12 мiс. & $0,142 \pm 0,043$ & $0,543 \pm 0,297$ & $0,088 \pm 0,078$ & $0,238 \pm 0,177$ & $0,739 \pm 0,337$ \\
\hline 15 мiс. & $0,247 \pm 0,057$ & $0,467 \pm 0,313$ & $0,175 \pm 0,065$ & $0,08 \pm 0,018$ & $0,647 \pm 0,381$ \\
\hline 18 мiс. & $0,201 \pm 0,019$ & $0,457 \pm 0,314$ & $0,087 \pm 0,057$ & $0,150 \pm 0,023$ & $0,351 \pm 0,268$ \\
\hline
\end{tabular}

Молодняк білоголової української породи помірного ступеня інбридингу позитивно реагуватиме на добір за живою масою при народженні лише для набору маси у віці 3 місяці. Залежність між іншими корелюючими ознаками мала як прямий, так і зворотний характер, але мала низький зв'язок. Не виявлено сильного зв'язку між досліджуваними корелюючими ознаками і серед тварин близького ступеня інбридингу. У телиць тісного ступеня інбридингу добір за

Вісник Сумського національного аграрного університету 
живою масою при народженні супроводжуватиметься зменшенням інтенсивності набору маси тварин у віці 3, 6 і 9 місяців з огляду на зворотний зв'язок між ознаками $(r=-$ $0,001 \ldots-0,739)$, але позитивно вплине на їх ріст у віці 12 і 15 місяців $(r=+0,647 \ldots+0,739)$. Визнано, що селекція аутбредних та інбредних телят за вищою живою масою при народженні здебільшого не впливатиме на позитивні зміни ознаки в процесі вирощування.

Крім визначення росту телиць білоголової української породи, одержаних в результаті спорідненого і неспорідненого підбору батьківських пар, зацікавленість викликала й їх відтворна здатність, оскільки чим раніше тварини будуть залучені в процес виробництва молока, тим прибутковість господарства буде вища.

Вивчивши основні показники відтворної здатності корів, за якими їх добирають для введення в стадо, ми дійшли висновку про доцільність розведення інбредних корів, оскільки їх майже на місяць раніше осіменяють і в результаті народжують телят, а значить і раніше від аутбредних починають давати прибуток від молока. Як видно з таблиці 3, перше плідне осіменіння аутбредних телиць I групи відбувалося на 0,5-0,9 міс. пізніше, ніж інбредних II - V груп. Серед інбредних телиць різного ступеня інбридингу вік першого осіменіння варіював у межах 19,4 -19,8 місяців і найвищим був у особин з віддаленим ступенем інбридингу.

Таблиця 3

Вік та жива маса першого осіменіння і отелення аутбредних та інбредних корів

\begin{tabular}{|c|c|c|c|c|c|}
\hline \multirow[b]{2}{*}{ Показник } & \multirow[b]{2}{*}{$\begin{array}{c}\text { I } \\
\text { (аутбри-динг) }\end{array}$} & \multicolumn{4}{|c|}{ Група (ступінь інбридингу) } \\
\hline & & $\begin{array}{c}\text { II } \\
\text { (віддалений) }\end{array}$ & $\begin{array}{c}\text { III } \\
\text { (помірний) }\end{array}$ & $\begin{array}{c}\mathrm{IV} \\
\text { (близький) }\end{array}$ & $\begin{array}{c}\mathrm{V} \\
\text { (тісний) }\end{array}$ \\
\hline $\mathrm{n}$ & 58 & 18 & 43 & 64 & 20 \\
\hline Вік першого осіменіння, міс & $20,3 \pm 0,68$ & $19,8 \pm 1,23$ & $19,4 \pm 0,69$ & $19,4 \pm 0,53$ & $19,4 \pm 0,89$ \\
\hline Жива маса першого осіменіння, кг & $350 \pm 9,87$ & $356 \pm 13,87$ & $351 \pm 9,67$ & $345 \pm 7,17$ & $371 \pm 18,46$ \\
\hline Вік першого отелення, міс & $29,8 \pm 0,71$ & $29,2 \pm 1,31$ & $28,8 \pm 0,73$ & $28,2 \pm 0,79$ & $29,3 \pm 1,24$ \\
\hline Жива маса першого отелення, кг & $483 \pm 5,87$ & $448 \pm 10,68$ & $491 \pm 28,82$ & $519 \pm 21,3$ & $506 \pm 30,37$ \\
\hline
\end{tabular}

В свою чергу вік першого отелення залежав від віку першого осіменіння й найбільшого значення мав у аутбредних корів - 29,2 місяці, що більше за інбредних на 0,5-0,6 місяців. Проте й за цими показниками у аутбредних та інбредних тварин не було виявлено статистично достовірної різниці, яка б засвідчувала перевагу спорідненого чи неспорідненого розведення худоби білоголової української породи.

Жива маса корів при першому осіменінні знаходилася у межах 345-371 кг, а першому отеленні -448-519 кг без чіткої узгодженості із спорідненістю тварин.

Надій корів I групи за 305 днів першої лактації стано-

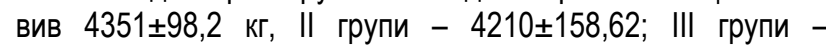

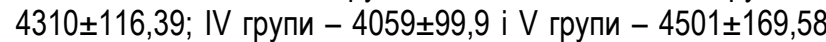
кг, відповідно. 3 огляду на надій корів-первісток зроблено висновок про деякий, в окремих випадках істотний, вплив спорідненого розведення на продуктивність тварин.

Встановлено, що аутбредні корови білоголової української породи за першу лактацію продукували на 41-292 кг молока більше, ніж інбредні віддаленого, помірного та близького ступенів інбридингу. Найвищий надій молока за першу лактацію був у корів V групи (тісний ступінь інбридингу), які на 150 кг перевищували продуктивність аутбредних корів і на 191-442 кг інбредних нижчого ступеня (II - IV групи). Проте і за даною ознакою між піддослідними тваринами не виявлено статистично достовірної різниці, що не дає підстав визначити перевагу того чи іншого методу розведення худоби білоголової української породи.

Підсумовуючи результати наших досліджень з вивчення продуктивності худоби білоголової української породи можна наголосити на тому, що споріднене розведення, яке приводить до появи в стаді інбредних тварин різних ступенів інбридингу, істотно не знижує їх продуктивність, порівняно з аутбредними, а за окремими ознаками такі тварини більш високопродуктивні. Тобто, в стаді білоголової української породи наявні інбредні корови, яких можна віднести до рекордисток, що узгоджується з можливістю отримання таких тварин в роботах інших дослідників [5], але при цьому слушна думка багатьох дослідників [2, 8, 22], які наголошують на необхідності контролювання рівня та ступеня інбридингу у потомства 3 тим, щоб не проявилися негативні наслідки спорідненого розведення у вигляді генетичних аномалій, нежиттєздатного потомства та низької продуктивності.

Висновки. 1. Між аутбредними та інбредними різного ступеня інбридингу телицями білоголової української породи не встановлено статистично достовірної різниці за живою масою при народженні та при вирощування до 18місячного віку, хоча споріднене розведення у більшості випадків сприяє їх вищій інтенсивності росту.

2. Добір як аутбредних, так і інбредних телят, крім віддаленого ступеня інбридингу, за живою масою при народженні не супроводжуватиметься високим показником у подальші вікові періоди, підтвердженням чого слугують слабкі прямі та зворотні зв'язки між ознаками.

3. Аутбредні корови пізніше за інбредних залучалися до відтворення за відсутності чіткого зв'язку між живою масою тварин під час першого осіменіння та отелення.

4. Розведення худоби білоголової української породи методами спорідненого розведення хоча й знижує надій за першу лактацію у групі корів віддаленого, помірного та близького ступенів інбридингу, порівняно до аутбредних, але ця різниця статистично недостовірна, що дає змогу застосовувати даний метод при відтворенні стада локальної породи.

\section{Список використаної літератури:}

1. Анисимова Е., Гостева Е. Эффективные приемы селекции симментальского скота. Молочное и мясное скотоводство. 2013. № 3. С. 19-21.

2. Бикадоров П. Інбридинг української чорно-рябої молочної худоби та господарськи корисні ознаки тварин. Тваринництво України. 2014. № 7. С. 14-17. 
3. Бабнеев С. А., Зеленовский О. А., Некрасов Д. К. Анализ результативности и целенаправленное планирование инбредного подбора при чистопородном разведении ярославского скота с использованием компьютерной программы. Аटрарный вестник Верхневолжья. 2014. № 4. С. 78-82.

4. Войтенко С. Л. Эфффективность применения инбридинга в закрытой популяции свиней. Зоотехния. 2003 . № 8. C. $13-14$

5. Влияние инбридинга на молочную продуктивность, воспроизводительную способность и экстерьер короврекордисток симментальской породы / Н. А. Кравченко и др. Молочно-мясное скотоводство. Харьков, 1985. Вып. 66. С. 1317.

6. Генетика і селекція у скотарстві / М. В. Зубець та ін. Генетика і селекція в Україні на межі тисячоліть. К.: Логос, 2001. T. 4. C. $181-198$.

7. До питання успадкування племінної цінності тварин у скотарстві / І. П. Петренко та ін. Вісник аграрної науки Причорномор'я. Миколаїв, 2012. Вип. 4 (69), т. 2, ч. 1. С. 120-124.

8. Дубинин Н. П., Глембоцкий Я. Л. Генетика популяций и селекция. М.: Наука, 1967. 591 с.

9. Дунин И. М. Труфанов В. Г., Новиков Д. В. Использование инбридинга в молочном скотоводстве. Зоотехния. 2012. № 9. С. 2-3.

10. Жебровський Л. С. Селекція тварин. С.-Пб.: Лань, 2002. 256 с.

11. Зверева Е. А., Муравьева Н. А. Эффективность применения инбридинга при разведении коров ярославской породы. Международный научно-исследовательский журнал. 2016. № 11 (53), ч. 5. C. 18-21. DOI: 10.18454/IRJ.2016.53.121.

12. Иванов М. Ф. Новая порода свиней - украинская степная белая, выведенная в Аскания-Нова, и методы ее образования. М.: Колос, 1964. Т. 5. С. 182-195.

13. Иванов М. Ф. Полное собрание сочинений. М.: Колос, 1970. Т. 5.258 с.

14. Инбридинг и племенная ценность быков-производителей / Костенко А. И. и др. Цитология и генетика. 1994. T. 26. № 1. С. 54-59.

15. Ерохин А. И. Солдатов А. П., Филатов А. М. Инбридинг и селекция животных. М., 1985. 164 с.

16. Кисловский Д. А. К вопросу об инбридинге. М.: Колос, 1965. С. 482-486.

17. Климова С. П., Шендаков А. И., Шендакова Т. А. Влияние степеней инбридинга на молочную продуктивность черно-пестрого голштинизированного скота. Весник ОрелГАУ. 2012. № 4 (12). С. 86-89.

18. Кравченко М. А. Теоретичні основи розведення тварин по лініях. Тваринництво України. 1969. № 11. С. 17-19.

19. Красота В. Ф., Лобанов В. Т., Джапаридзе Т. Г. Разведение сельскохозяйственных животных. М.: Агропромиздат, 1990. 463 c.

20. Кушнер Х. Ф. Наследуемость и повторяемость признаков животных, методы определения и значение для селекции. Животноводство. 1964. № 2. С. 80-85.

21. Ладика В. І. Ефективність спорідненого спарювання в селекції бугаїв-плідників бурих порід. Вісник аграрної науки. 1998. № 6. C. 52-54.

22. Любимов А. И., Юдин В. М. Инбридинг в селекции черно-пестрого скота Удмуртской Республики. Зоотехния. 2012. № 10. C. 2-3.

23. Микитас Р. Є., Демчук В. В., Папакіна Н. С. Прогнозування молочної продуктивності корів червоної степової породи різного ступеня інбридингу. Таврійський науковий вісник. 2001. Вип. 17. С. 59-62. C. 107-110.

24. Підпала Т. В. Великомасштабна селекція і розведення за лініями. Розведення і генетика тварин. 2005. Вип. 38.

25. Підпала Т. В. Породотворний процес та інбридинг у молочному скотарстві. Розведення і генетика тварин. 2007. Вип. 41. С. 164-171. 1986. $191 \mathrm{c}$.

26. Прохоренко П. Н., Логинов Ж. Г. Межпородное скрещивание в молочном скотоводстве. М.: Россельхозиздат,

27. Разведение сельскохозяйственных животных с основами частной зоотехнии и промышленного животноводства / Н. Г. Дмитриев и др. Л.: Агропромиздат, 1989. 511 с.

28. Рудик І. А., Ставецька Р. В. Консолідованість та спорідненість ліній голштинської породи в Україні. Технологія виробництва і переробки продукції тваринництва. Біла Церква, 2010. Вип. 3 (72). С. 3-8.

29. Сірацький Й. 3. Робота з лініями в сучасних умовах. Розведення і генетика тварин. 2005. Вип. 38. С. 74-77.

30. Солдатов А. П., Сперанский А. Т. Влияние инбридинга на молочную продуктивность крупного рогатого скота швицкой породы. Генетические основы повышения продуктивности сельскохозяйственных животных: сб. науч. тр. ВСХИЗО. Москва, 1975. Вып. 96. С. 15-21.

31. Теорія системного аналізу «кровозмішення» у тварин / Петренко І. П. та ін. К.: Аграрна наука, 2005. 521 с.

32. Inbreeding depression for global and partial economic indexes, production, type, and functional traits / Croquet C. I. et al. Journal of Dairy Science. 2006. Vol. 93, Issue 7. P. 2257-2267. doi:10.3168/jds.S0022-0302(06)72297-4.

33. Cassell P. G. Inbreeding. Virginia Coop. Extension, 1999. P. 404-480.

34. Ensminger M. E. Dairy cattle science. Third Edition. Danville, Illinois: Interstate Publishers, 1993. P. 71-91.

35. Evaluation of inbreeding depression in Holstein cattle using whole-genome SNP markers and alternative measures of genomic inbreeding / D. W. Bjelland et al. Journal of Dairy Science. 2013. Vol. 96, Issue 7. P. 4697-4706. DOI: https://doi.org/10.3168/ids.2012-6435.

36. Morris C. Inbreeding in cattle and its conseguencer. Austral Country Magazine. 1980. Vol. 47, № 3. P. 24. Вісник Сумського національного аграрного університету 
37. Monitoring inbreeding trends and inbreeding depression for economically important traits of Holstein cattle in Iran / M. I. Rokouei et al. Journal of Dairy Science. 2010. Vol. 93, Issue 7. P. 3294-3302. DOI: https://doi.org/10.3168/jds.2009-2748.

38. Segkora T., Daniel V. How to avoid inbreeding problems. Dairy Herd Manog.1982. Vol. 19, № 12. P. 145-148.

39. Smith L. A., Cassell B. G., Pearson R. E. The effects of inbreeding on the lifetime performance of dairy cattle. Journal of Dairy Science. Vol. 81 Issue 10. P. 2729-2737. https://doi.org/10.3168/jds.S0022-0302(98)75830-8.

\section{References:}

1. Anisimova, E. and Gosteva, E. 2013. Effektivnye priemy selektcii simmentalskogo skota [Effective breeding techniques for Simmental cattle]. Molochnoe i mjasnoe skotovodstvo, no. 3, pp. 19-21.

2. Bykadorov, P. 2013. Inbrydynh ukrainskoi chorno-riaboi molochnoi khudoby ta hospodarsky korysni oznaky tvaryn [Impact inbreeding to economically valuable trainian Black-Motley Dairy cattle]. Tvarynnytstvo Ukrainy, no. 3, pp. 19-21.

3. Babneev, S. A., Zelenovski, O. A. and Nekrasov, D. K., 2014. Analiz rezultativnosti i tcelenapravlennoe planirovanie inbrednogo podbora pri chistoporodnom razvedenii iaroslavskogo skota s ispolzovaniem kompiuternoi programmy [Performance analysis and purposeful planning of inbred selection in purebred breeding of Yaroslavl cattle using a computer program]. Agrarnyi vestnik Verkhnevolzhia, no 4, pp. 78-82.

4. Voitenko, S. L., 2003. Effektivnost primeneniia inbridinga v zakrytoi populiatcii svinei [The effectiveness of inbreeding in a closed population of pigs]. Zootechniya, no 8, pp. 13-14.

5. Kravchenko, N. A., [et al.], 1985. Vliianie inbridinga na molochnuiu produktivnost, vosproizvoditelnuiu sposobnost i eksterer korov-rekordistok simmentalskoi porody [Influence of inbreeding on milk productivity, reproductive ability and conformation of recordbreaking cows of the Simmental breed]. Dairy and beef cattle Farming, vol. 66, pp. 13-17.

6. Zubetc, M. V., [et al.], 2001. Henetyka i selektsiia u skotarstvi [Genetics and selection in Ukraine at the turn of the millennium]. K.: "Lohos", vol. 4. pp. 181-198.

7. Petrenko, I. P., [et al.], 2012. Do pytannia uspadkuvannia pleminnoi tsinnosti tvaryn u skotarstvi [To the question of pedigree value heritability by cattle]. Visnyk ahrarnoi nauky Prychornomor'ia, Issue 4 (69), vol. 2, part 1, pp. 120-124.

8. Dubinin, N. P. and Glembotckii, la. L., 1967. Genetika populiatcii i selektciia [Population genetics and breeding]. Moscow: Nauka.

9. Dunin, I. M., Trufanov, V. G. and Novikov, D. V., 2012. Ispolzovanie inbridinga v molochnom skotovodstve [The use of inbreeding in dairy cattle]. Zootekhniia, no. 9, pp. 2-3.

10. Zhebrovskii, L. S., 2002. Selektsiia tvaryn [Selection of animals]. S.-Pb.: «Lan».

11. Zvereva, E. A. and Muraveva, N. A., 2016. Effektivnost primeneniia inbridinga pri razvedenii korov iaroslavskoi porody [The effectiveness of the use of inbreeding in the breeding of cows of the Yaroslavl breed]. Mezhdunarodnyi nauchno-issledovatelskii zhurnal, no 11 (53), part 5, pp. 18-21. DOI: 10.18454/IRJ.2016.53.121.

12. Ivanov, M. F., 1964. Novaia poroda svinei - ukrainskaia stepnaia belaia, vyvedennaia v Askaniia-Nova, i metody ee obrazovaniia [A new breed of pigs - Ukrainian Steppe White, bred in Askania-Nova, and methods of its education]. Moscow: Kolos, vol. 5 , pp. 182-195.

13. Ivanov, M. F., 1970. Polnoe sobranie sochinenii [Full composition of writings]. M.: Kolos, vol. 5, $258 \mathrm{p}$.

14. Kostenko, A. I., [et al], 1994. Inbriding i plemennaia tcennost bykov-proizvoditelei [Inbreeding and breeding value of sire bulls]. Tcitologiia i genetika, vol. 26, no 1, pp. 54-59. Moskva.

15. Erokhin, A. I., Soldatov, A. P., and Filatov, A. M., 1985. Inbriding i selektciia zhivotnykh [Inbreeding and selection of animals].

16. Kislovskii, D. A., 1965. K voprosu ob inbridinge [On the question of inbreeding]. M.: Kolos, pp. 482-486.

17. Klimova, S. P., Shendakov, A. I. and Shendakova, T. A., 2012. Vliianie stepenei inbridinga na molochnuiu produktivnost cherno-pestrogo golshtinizirovannogo skota [Influence of the degrees of inbreeding on the milk productivity of Black-and-White Holstein cattle]. Vesnik OrelGAU, no 4(12), pp. 86-89.

18. Kravchenko, M. A., 1969. Teoretychni osnovy rozvedennia tvaryn po liniiakh [Theoretical foundations of animal breeding along the lines]. Tvarynnytstvo Ukrainy, no 11, pp. 17-19.

19. Krasota, V. F. Lobanov, V. T., and Dzhaparidze, T. G., 1990. Razvedenie selskokhoziaistvennykh zhivotnykh [Breeding of farm animals]. M.: "Agropromizdat".

20. Kushner, Kh. F., 1964. Nasleduemost i povtoriaemost priznakov zhivotnykh, metody opredeleniia i znachenie dlia selektcii [Heritability and repeatability of animal traits, methods of determination and significance for selection]. Zhivotnovodstvo, no 2, pp. 80-85.

21. Ladyka, V. I., 1998. Efektyvnist sporidnenoho spariuvannia v selektsii buhaiv-plidnykiv burykh porid [The efficiency of related mating in the selection of breeding bulls of brown breeds]. Visnyk ahrarnoi nauky, no 6, pp. 52-54.

22. Liubimov, A. I. and ludin, V. M., 2012. Inbriding v selektcii cherno-pestrogo skota Udmurtskoi Respubliki [Inbreeding in selection of Black-and-White cattle of Udmurt Republic]. Zootekhniia, no 10, pp. 2-3.

23. Mykytas, R. Ye., Demchuk, V. V., and Papakina, N. S., 2001. Prohnozuvannia molochnoi produktyvnosti koriv chervonoi stepovoi porody riznoho stupenia inbrydynhu [Prediction of milk productivity of cows of Red Steppe breed of different degree of inbreeding]. Tavriiskyi naukovyi visnyk, vol. 17, pp. 59-62.

24. Pidpala, T. V., 2005. Velykomasshtabna selektsiia i rozvedennia za liniiamy [Largly scale selection and cultivation on lines]. Rozvedennia i henetyka tvaryn, vol. 38, pp. 107-110.

25. Pidpala, T. V., 2007. Porodotvornyi protses ta inbrydynh u molochnomu skotarstvi [Breeding process and inbreeding in the dairy cattle]. Rozvedennia i henetyka tvaryn, vol. 41, pp. 164-171. 
26. Prokhorenko, P. N. and Loginov Zh. G., 1986. Mezhporodnoe skreshchivanie v molochnom skotovodstve [Interbreeding in dairy farming]. Moscow: Rosselkhozizdat.

27. Dmitriev N. G., [et al.], 1989. Razvedenie selskokhoziaistvennykh zhivotnykh s osnovami chastnoi zootekhnii i promyshlennogo zhivotnovodstva [Breeding farm animals with the basics of private animal husbandry and industrial animal husbandry]. Agropromizdat.

28. Rudyk, I. A., and Stavetska, R. V., 2010. Konsolidovanist ta sporidnenist linii golshtinskoï porodi v Ukraïni [Consolidation and cognation of Holstein breed lines in Ukraine]. Tekhnolohiia vyrobnytstva i pererobky produktsii tvarynnytstva, vol. 3 (72), pp. 3-8.

29. Siratskyi, Y. Z., 2005. Robota z liniiamy v suchasnykh umovakh [Working with lines in modern conditions]. Animal Breeding and genetics. vol. 38. pp. 74-77.

30. Soldatov, A. P., Speranskii, A. T. 1975. Vliianie inbridinga na molochnuiu produktivnost krupnogo rogatogo skota shvitckoi porody [The influence of inbreeding on dairy productivity of cattle of Swiss breed]. Genetic bases of increase of productivity of farm animals: collection of scientific papers VSKHIZO. Moskva, vol. 96, pp. 15-21.

31. Petrenko I. P. [et al.], 2005. Teoriia systemnoho analizu «krovozmishennia» u tvaryn [Theory of system analysis of "incest" in animals]. K.: "Ahrarna nauka".

32. Croquet C. I., [et al.], 2006. Inbreeding depression for global and partial economic indexes, production, type, and functional traits. Journal of Dairy Science, vol. 93, issue 7, pp. 2257-2267. doi:10.3168/jds.S0022-0302(06)72297-4.

33. Cassell, P. G., 1999. Inbreeding. Virginia Coop. Extension, pp. 404-480.

34. Ensminger, M. E., 1993. Dairy cattle science. Third Edition. Danville, Illinois: Interstate Publishers, pp. 71-91.

35. Bjelland, D. W., [et al.], 2013. Evaluation of inbreeding depression in Holstein cattle using whole-genome SNP markers and alternative measures of genomic inbreeding. Journal of dairy science, vol. 96, issue 7, pp.4697-4706. DOI: https://doi.org/10.3168/jds.2012-6435.

36. Morris C., 1980. Inbreeding in cattle and its conseguencer. Austral Country Magazine, vol. 47, no 3, pp. 24.

37. Rokouei, M. I, [et al.], 2010. Monitoring inbreeding trends and inbreeding depression for economically important traits of Holstein cattle in Iran. Journal of Dairy Science, vol. 93, issue 7, pp. 3294-3302. DOI: https://doi.org/10.3168/jds.2009-2748.

38. Segkora, T. and Daniel, V., 1982. How to avoid inbreeding problems. Dairy Herd Manog, vol. 19, no 12, pp. 145-148.

39. Smith, L. A., Cassell, B. G. and Pearson, R. E., 1998. The effects of inbreeding on the lifetime performance of dairy cattle. Journal of Dairy Science, vol. 81, issue 10, pp. 2729-2737. https://doi.org/10.3168/jds.S0022-0302(98)75830-8.

Voitenko S. L. Doctor of Agricultural Sciences, Professor,

Sydorenko O.V. PhD of Agricultural Sciences, Senior researcher

Institute of Animal Breeding and Genetics nd. a. M.V.Zubets of National Academy of Agrarian Science of Ukraine

Productivity of outbreed and inbreed cattle of Ukrainian White-headed breed

Among the methods of purebred breeding of farm animals, researchers are particularly interested in inbreeding, without which it is impossible to do not only in the breeding of farm animals, but also in preserving the biological diversity and unique qualities of local breeds. And although the problem of inbreeding has a long history of study, it is quite complex and multifaceted even now, with the modern development of genetics and selection, which requires further work, finding ways to manage the herd and breed, especially when the breed is small and bred in a closed population. The research was conducted on outbred and inbred heifers and white-headed cows of Ukrainian breed in LLC "Podilsky Gospodar" of Khmelnytsky region, which were divided into 5 experimental groups depending on the degree of relatedness and inbreeding rate. We studied the live weight of heifers in the process of rearing, reproductive ability and hopes of first-born cows on the basis of the database of the dairy management system of SUMS "Intesel-Orsek". It was found that outbred and inbred heifers of the Ukrainian White-headed breed in the process of rearing from birth to 18 months of age differed in live weight, but the difference between the groups was statistically insignificant. In different periods of growth, both outbred and inbred animals were preferred, indicating the possibility of use in the herd along with unrelated breeding of related. In general, during the period of growth from birth to 18 months of age, outbred heifers in live weight outperformed animals of the group of remote and close inbreeding by $6.0 \mathrm{~kg}$ and $2.0 \mathrm{~kg}$, but were inferior to the representatives of moderate and close inbreeding by 3.0 and $13.0 \mathrm{~kg}$, respectively. The expediency of obtaining and using inbred animals of the Ukrainian White-headed breed is confirmed by the results of studying the reproductive capacity of cows, according to which inbred cows were inseminated for the first time 0.5-0.9 months earlier than outbred ones. At the same time, outbred blood during the first lactation produced 41-292 kg more milk than inbred blood of distant, moderate and close inbreeding rates, but $150 \mathrm{~kg}$ less than the group of cows of close inbreeding without statistically significant difference between groups. With this in mind, a generalized conclusion was made about the possibility of related breeding of Ukrainian White-headed breed of cattle.

Key words: breeding methods, local breed, cattle, growth, productivity.

Дата надходження до редакції: 09.09.2020 p. 